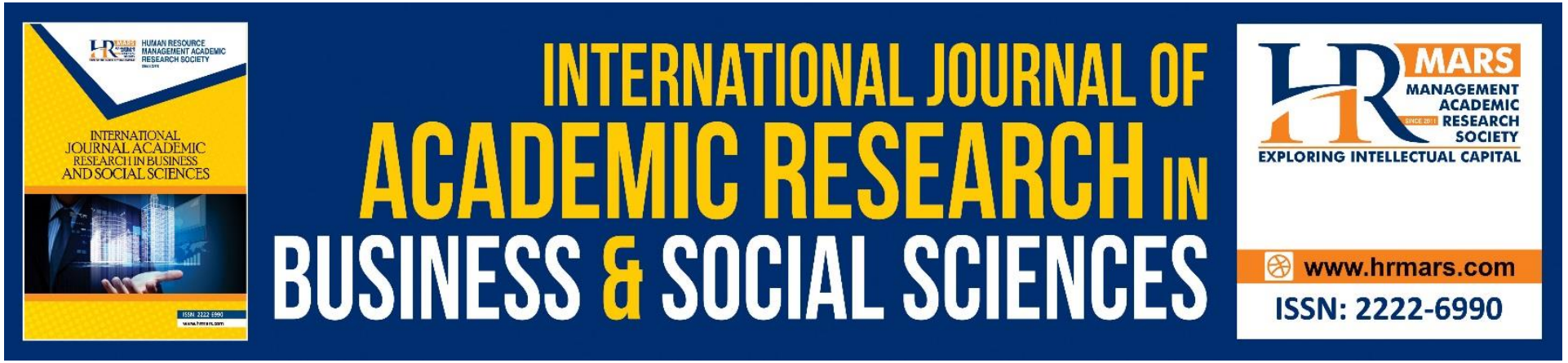

\title{
Malaysian Rural Primary School Students' Perceptions of Experiences towards Second Language Learning
}

Farouk Rupiwin, Parilah Mohd Shah

To Link this Article: http://dx.doi.org/10.6007/IJARBSS/v11-i9/10675

DOI:10.6007/IJARBSS/v11-i9/10675

Received: 07 July 2021, Revised: 27 July 2021, Accepted: 18 August 2021

Published Online: 06 September 2021

In-Text Citation: (Rupiwin \& Shah, 2021)

To Cite this Article: Rupiwin, F., \& Shah, P. M. (2021). Malaysian Rural Primary School Students' Perceptions of Experiences towards Second Language Learning. International Journal of Academic Research in Business and Social Sciences, 11(9), 68-96.

\section{Copyright: @ 2021 The Author(s)}

Published by Human Resource Management Academic Research Society (www.hrmars.com)

This article is published under the Creative Commons Attribution (CC BY 4.0) license. Anyone may reproduce, distribute, translate and create derivative works of this article (for both commercial and non-commercial purposes), subject to full attribution to the original publication and authors. The full terms of this license may be seen at: http://creativecommons.org/licences/by/4.0/legalcode

Vol. 11, No. 9, 2021, Pg. 68 - 96

Full Terms \& Conditions of access and use can be found at http://hrmars.com/index.php/pages/detail/publication-ethics 


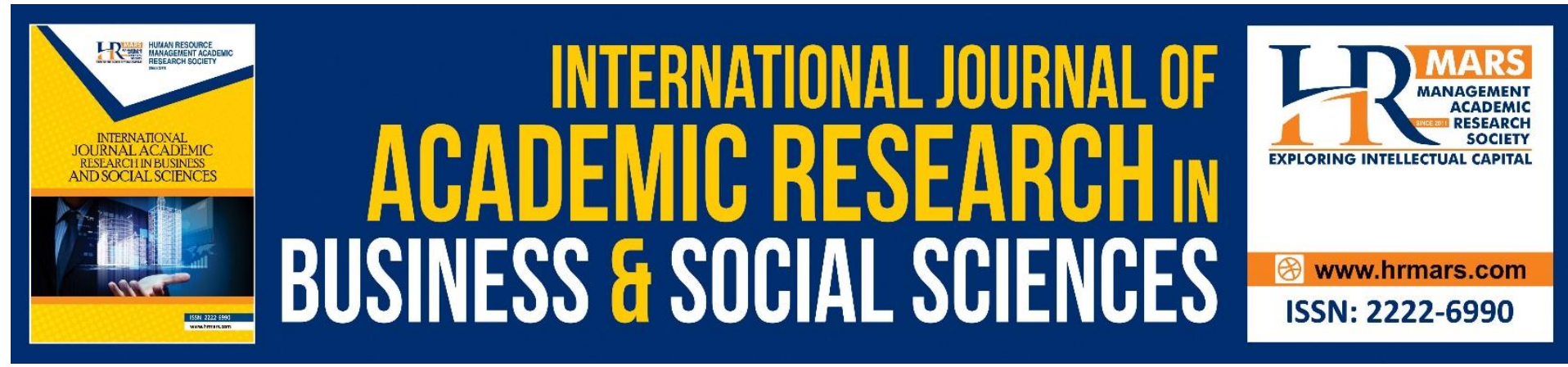

\title{
Malaysian Rural Primary School Students' Perceptions of Experiences towards Second Language Learning
}

\author{
Farouk Rupiwin, Parilah Mohd Shah \\ Faculty of Education, Universiti Kebangsaan Malaysia, Selangor, MALAYSIA. \\ Email: farouk.rupiwin@gmail.com,drparila@gmail.com
}

\begin{abstract}
Research on language learning in rural areas and in a multilingual context is an underrated study. It is apparent that most research on language learning is primarily focusing more in urban areas. Malaysia is an exemplary setting for multilingualism, with a large number of primary schools located in rural areas. As a result, a study was conducted using a survey research design to investigate second language learning in a rural school from a multilingual perspective. This study investigated the aspect of language attitude and language academic skills in terms of English language learning based on the perceptions of students from a rural primary school in Beluran, Sabah. Krashen's Natural Approach provided insights into various aspects of the research, specifically through the lens of the affective filter hypothesis and the input hypothesis. A total of 27 primary students from Year 5 and 6 were chosen as research participants. Data was collected using a questionnaire adapted from Sparks, Ganschow, and Javorsky's (1993) Foreign Language Attitude and Perceptions Survey (FLAPS). The questionnaire items focused on language attitude and language academic skills in a Likert Scale design. The data collected was then analysed using frequency analysis through Statistical Package for the Social Science (SPSS) software platform. The findings depicted that a majority of the respondents demonstrated positive language learning readiness and attitudes. However, it did not change the fact that due to their low level of proficiency in the target language, a majority of them experienced anxiety and lack of confidence in learning the English language. As a result, classroom pedagogy should be adjusted to meet the needs and proficiency levels of the students. Furthermore, the government should prioritise infrastructure development and resources for rural schools.
\end{abstract}

Keywords: Rural Primary School, Language Attitude, Language Academic Skills, Foreign Language Attitude and Perceptions Survey (FLAPS), Proficiency Level.

\section{Introduction}

\section{Status of the English Language in Malaysia}

Unilingualism or commonly known as monolingualism, is losing ground around the world in favour of multilingualism. Malaysia's primary language communication system is Malay, Chinese, and Tamil, which are primarily communicated through three major local languages. Children in primary school have the option of attending national schools or private schools. 
Loo (2007) elaborated that the curriculum in the national schools is primarily taught in Malay, the national language. On the other hand, Vernacular schools predominantly use Mandarin and Tamil languages as the medium of instruction according to the type of vernacular schools. This division, however, no longer applies at the secondary education level, whereby all subjects are taught in the national language. The private running of the Chinese secondary schools gives the possibility to take national public examinations to students registered in these schools. Meanwhile, Malaysia has no Tamil secondary schools. Thus, the existence of many languages amongst the citizens is affected by their social backgrounds and heritage. Multilingualism can be regarded as an economic good and, as such, valued. The situation with multilingual languages presents an interesting supply and demand curve, where supply, particularly for a language of wider communication, is frequently determined by institutional constraints (Zhou \& Xiaomei, 2017). The demand curve is related to the language's "status" and the level of social cohesion in the community to which the language is being passed on. A language is an important part of a community, shaping and building its identity in the same way that physical heritage does. As a result, its existence must be valued and preserved in the same way that a region's cultural and environmental heritage are.

Second language learning (SLL) is popular among Malaysians because Bahasa Melayu is the country's national language, and English is an official language. The English language is used extensively in Malaysian education, where it is regarded as a second language (L2) and a language of knowledge. Furthermore, both primary and secondary schools require students to pass the English Language subject (Jafar, 2015). As a result, in order to achieve bilingual proficiency, it is reasonable to expect English to be prioritised as the national language. This general discussion has not extended to those who have adopted their ethnic languages as their first language. For example, Chinese people have adopted Mandarin, Hokkien, and other languages as their first language (L1). This means that for the vast majority of them, English is their second or even third language. Bilingualism is associated with knowing one's native language first, followed by English. This concept is simply expected in a society with many language speakers. Living in a racially diverse country like Malaysia, the case of multilingualism among the society is a common occurrence.

The development of the education system in Malaysia is worth a vigorous and strenuous effort in order to have compromise amongst the citizens. This is because Malaysia's education system is divided into two types of schools: national and vernacular schools. Children in national schools are primarily taught in Malay, also known as Bahasa Malaysia. Others who attend national type schools that are also vernacular type schools are taught in vernacular languages such as Mandarin or Tamil. Such a phenomenon appears to exist only in Malaysia. Furthermore, Malaysia allows the operation of private schools, which tend to cater to those who are either more financially endowed or families who intend to send their children abroad for higher education. In this case, while the Malay language has been designated as an official national language, it also has a liberal language policy that allows minorities or other institutional languages such as English or Mandarin to be included in its education system (Gill, 2008). At the tertiary level, it is widely acknowledged that the English Medium of Instruction (EMI) phenomenon is spreading rapidly around the world (Macaro 2018; Macaro et al., 2018; Wächter \& Maiworm, 2014). 


\section{Perception towards Second Language Learning in Malaysia}

Based on the standard created by the Ministry of Education Malaysia (MOE) in the Malaysia Education Blueprint 2013-2025, Malaysia's education system has grown enormously over the decades. The blueprint is consistent with the National Education Philosophy (1988) published by the MOE (1988), which stated the education vision in developing students who are developed holistically from the intellectual, spiritual, emotional, and physical dimensions. Malaysian children are prepared to compete on a global scale by adhering to the system's goals of access, quality, equity, unity, and efficiency (MOE, 2013).

Malaysia's score dropped from 26th in 2019 to 30th in 2020 out of 100 countries or regions, much to the country's chagrin, according to the EF English Proficiency Index (2020). This emphasises the need of improving English language proficiency in accordance with the benchmark established in the English Language Education Reform in Malaysia: The Roadmap (2015-2025), which states that at the conclusion of primary school, students should have an A2 basic band (Don et al., 2015). As a result, the Common European Framework of Reference for Languages (CEFR) is being used to implement reformed language learning, teaching, and assessment in Malaysia for the English Language topic.

Despite the fact that the English language has been a compulsory subject taught in the primary and secondary schools in Malaysia, statistics showed a deterioration in Malaysian students' English proficiency levels. Gill (2014) stated that English is the poorest subject among students in national exams, with $22 \%$ of Malaysian students failing SPM and $25 \%$ failing UPSR. Malaysian students failed 50\% of international assessments, such as the 1119 SPM paper. Many university graduates are unable to find work because they lack the necessary English skills. In the Malaysian University English Test (MUET), 52 percent scored only Band 1 and 2 on the scale, the two lowest bands.

\section{The Teaching of the English Language in Malaysia}

English is becoming universal in many academic disciplines, and internationalisation is being realised in many higher education institutions through the English language implementation in the curriculum. Due to this change in the medium of instruction, English has progressed from being taught as a foreign language alongside other school subjects to becoming a vital educational language used for learning and teaching all academic subjects in order to prepare students for their tertiary level of education. Malaysia's education system has grown enormously over the decades, according to the standards established by the Ministry of Education Malaysia (MOE) in the Malaysia Education Blueprint 2013-2025. The blueprint is consistent with the MOE's National Education Philosophy (1988), which stated the education vision of developing students holistically from the intellectual, spiritual, emotional, and physical dimensions. Malaysian children are ready to compete on a global scale because they adhere to the system's goals of access, quality, equity, unity, and efficiency (MOE, 2013).

English language teachers in Malaysia have been teaching against the backdrop of ongoing educational reforms since the country's independence. In an ironic twist, the media blames English language teachers rather than the system for falling standards (Aruna 2014; Jalleh 2013). The English Language Standards and Quality Council (ELSQC) was established in 2013 to implement the CEFR in Malaysia. The Council assisted the English Language Teaching Center (ELTC) in assisting the Ministry of Education in elevating and improving the English 
language ability of Malaysian students. The council was in charge of incorporating the CEFR framework into the educational system as well as developing a reform plan for English language education. The Malaysia Education Blueprint emphasises the importance of aligning the educational system with the CEFR in order to raise the level of education to international standards (Azman, 2016). The roadmap is a long-term goal and strategy that began in 2013 and is scheduled to end in 2025. The primary goal is to provide the best language education from preschool to postsecondary education.

\section{Rationale of the Research}

The unintended emergence of the Covid-19 pandemic since 2020 has thus drawn attention to the need to put the country's educational system to the test, as not every student has the resources required for virtual or digital learning and training courses (Salleh et al., 2020). This has a significant impact on the learning environment and the learning process of the students.

Language learning as a second language in Malaysia is difficult for both teachers and students, even in schools where face-to-face interactions are possible (Azman, 2016). This forced scenario during the epidemic exacerbates the situation as a result of changing educational standards. This is especially concerning for students from rural areas. The rural concept is interpreted differently by different people. Herzog and Pittman (1995), for example, define rural as "any area that is not (part of) a city" (or non-metropolitan area). On the other hand, Othman and Mujis (2013) offered a more abstract concept, stating that rural is the polar opposite of urban. If a large number of people populates the urban area, the rural area is populated by a small number of people.

According to Johnson and Strange (2005), a rural school is a metropolitan area with a population of fewer than 2,500 people. Regardless, the government had devised strategies and measures to address the issues. As a result, the research was carried out based on the current state of the education system during the pandemic, whereby teaching and learning is done remotely. However, it cannot be used to excuse the students' poor perceptions and performance in the English language compared to Malaysian students who live in urban areas. The English proficiency level of urban students is higher than that of rural students (Ghazali, 2016).

Furthermore, Thang, Ting, and Ling (2012) stated that one of the factors contributing to low competence and low passing rates in schools is the attitudes and motivation of these children who live in rural and remote areas toward studying English. According to Rashid, Vethamani, and Rahman (2010), teaching English in less developed regions can be difficult due to students' low proficiency and a lack of school facilities. Given the likely difficulties in the teaching situation, teachers in these areas are likely to require assistance. In fact, the disparity between rural and urban students is so great that students from both groups attribute different explanations for their success and failure in learning English as a second language. Only students from middle and upper-middle-class families speak English as a first language; the majority of students are illiterate, making language instruction difficult (Rashid, 2016). The urban students were more willing to attribute their success to their own talent, effort, and study skills than the rural students (Gobel et al., 2013). 


\section{Research Objective}

a. This research intends to provide more information based on perspectives from rural primary students in Sabah, Malaysia, as related to language attitude and language academic perceptions.

\section{Research Questions}

b. What are the students' perceptions towards second language learning as related to language attitudes in SK Lidong?

c. What are the students' perceptions towards second language learning as related to language academic skills in SK Lidong?

\section{Literature Review}

\section{Conceptual Framework}

One of the major approaches that is related to SLL, motivation, attitude in language learning, and language acquisition was proposed by Krashen (1981) in his notion of Natural Approach. The Natural Approach was supported by Krashen's theory that comprises five hypotheses: the Acquisition-Learning hypothesis, the Monitor hypothesis, the Natural Order hypothesis, the Input hypothesis, and the Affective Filter hypothesis (1983). Language learning is a disparate aspect compared to language acquisition. Essentially, Krashen (1983) defined the occurrence of language learning as taking place in a formal setting whereby the learners are aware or conscious of the language components that they are learning, and they also learn the application of it. Contrastingly, language acquisition is an unconscious cognitive process and development closely related to acquiring one's first language. The specificity of this research is pinpointed on rural primary students and their perceptions towards SLL, the English language, in the aspects of language attitude and language academic skill. The conceptual framework is shown in Figure 1.

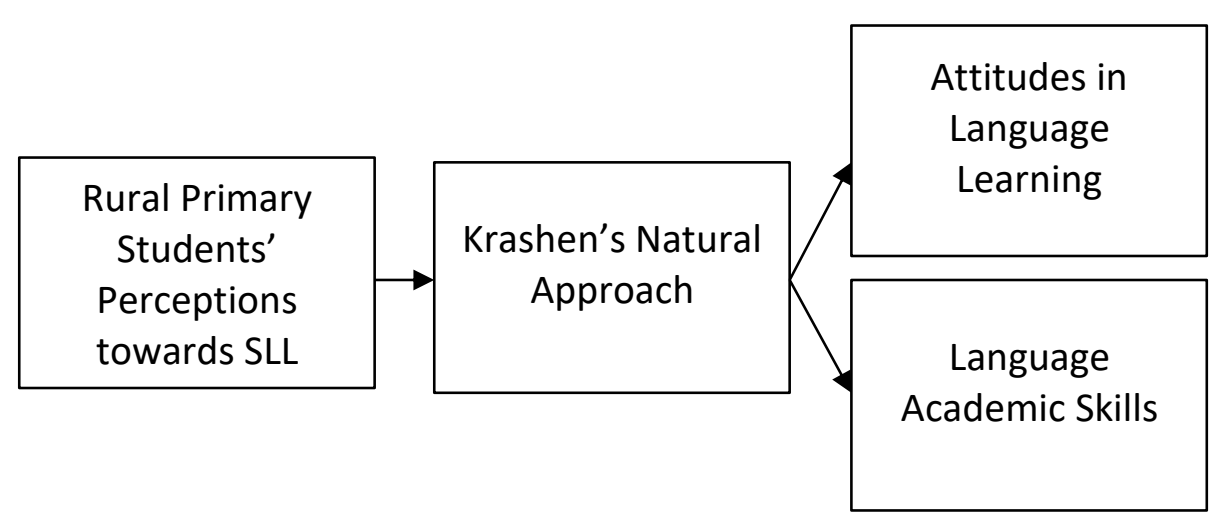

Figure 1 Conceptual framework adapted from Krashen (1981)

\section{Language Attitudes}

Different people have different sets of attitudes towards language that they have acquired or in the process of learning. Language attitudes are the foundation for a society's acceptance and growth of language varieties. This is especially crucial in the context of a multilingual society. When the standard norm of a language and its non-native variety are used almost simultaneously, the users of these languages can provide insights into language trends. 
Perceptions and attitudes are indicators of whether a variety of English is growing or declining. Language attitudes refer to how speakers of different languages or dialects perceive one another's or their own languages. Positive or negative attitudes toward a language may reflect perceptions of linguistic complexity or simplicity, ease or difficulty of learning, significance, elegance, social standing, and so on. People's attitudes toward a language can also reveal how they feel about the people who speak it. One's attitude can influence one's ability to learn a second or foreign language. Language attitude measurement provides data that can be used to improve language education and planning. According to Bartram (2010), language attitude is a mental and neurological state of readiness that is organised by experience and has a directive or dynamic impact on an individual's reaction to all subjects and circumstances with which it is associated. Brown (2000) explained that attitude formation, like other aspects of cognition and affect development in humans, occurs early in life as a result of parental and peer attitudes, interactions with people who are "different" in a variety of ways, and exposure to fascinating emotional components of the human experience. Students' attitudes are influenced by their perceptions of both the target language culture and their own culture, which usually begins at home (Ellis \& Shintani, 2014).

A successful language student must be able to identify with native speakers of the language (Gajalakshmi, 2013). The students will pick up on or adopt aspects of the target language culture or society's behaviour. One's perception of the language typically determines one's sense of openness. Thus, looking through the perspective of Krashen's Natural Approach, the affective filter hypothesis is related to how language attitude develops or can be affected. Krashen's (1983) affective filter hypothesis stated that the ability to reduce one's emotive filters and allow in basic understandable material is critical to learning a second language.

The theory's proponents mention a variety of emotional components, including selfconfidence, worry, and attitude. Krashen's main principles govern the affective concept, which includes the following: affective factors have no effect on first language acquisition, affective filters are responsible for individual variations in second language acquisition, people with lower affective filters acquire and encounter more profound input, and those with higher affective filters limit the amount of comprehensible input (Du, 2009). As a result, in order to facilitate effective language learning, learners' affective filters should be lowered. Hence, one's affective filter in language learning contributes to the formation of the language attitude either negatively or positively.

\section{Language Academic Skills}

The control of academic language appeared to be a need for success in difficult literacy activities such as reading textbooks or writing research papers and journals. Early in primary school, students are expected to acquire new knowledge from the subject matter of textbooks, which can impede their acquisition of the academic language of such materials. Concerns about students' achievement were linked to educators' lack of "academic language skills" (August \& Shanahan 2006; Halliday \& Martin 1993; Pilgreen 2006; Schleppegrell \& Colombi 2005). The researchers emphasised the importance of teachers' language academic skills to convey that the learners' success in attaining a certain level of the skills depends on the educators. 
Students could also progress autonomously in their academic language development by teaching them about strategies for encoding complicated information - both as an approach to reading and as an input to academic writing. However, in this case, the aim may mainly be to increase the learner's repertory of viable messages, since young children experience difficulties from the first months of their speech in expressing complicated concepts with limited language skills (Gelman et al., 1998). Any educational programme should include strategies to help students feel comfortable expressing who they are and what they bring to school.

Simultaneously, schools have a moral obligation to provide equitable opportunities for all students to engage in intellectual discourse, which is a prerequisite for eventual academic achievement. Children's education can be rooted in their own culture while still emphasising the skills required for academic success in school (Delpit, 1995). In consideration of the target language learning context, the suitability of the information or content delivery is one of the factors that can affect the learners' achievement. Thus, as can be seen from Krashen's (1985) Input Hypothesis, it provides insights into how pedagogies in schools should be conducted to aid students' SLL processes. The $i+1$ is a crucial feature of this hypothesis. It places a strong emphasis on the phrase "comprehensible input" (White, 1987). The letter "I" represents the learners' previous knowledge of extra-linguistic and linguistic competence, while the letter " +1 " represents comprehensible input at a level higher than their previous knowledge or skill (Krashen 1992; Gass \& Mackey 2007). By applying it in an English Language Teaching (ELT) classroom, the emphasis on comprehensible input can be further elucidated. In any lesson, second language learners will struggle to understand certain input provided by the teacher due to limitations such as mother tongue interference, slow learner, lack of focus, and others (Ehrman 1996; Kormos 2016). Hence, in the context of learning English as a second language in a formal setting, the resources and materials for teaching are vital to be altered according to the learners' proficiency level.

\section{Previous Research Findings}

The demarcation of acquisition-learning defines the study's theoretical focus within the context of second language learning. Schmidt (1990), a linguist, stated an interesting academic debate about the state of language learning. Bialystok (1978) presented a theoretical framework in the discourse of condition in language learning that explains the role of knowledge in a conscious manner. Rutherford and Sharwood Smith (1985) supported the proposition by focusing on the critical aspect of raising consciousness in formal language learning. Surprisingly, some linguists believe that language learning should and does occur unconsciously (Seliger 1983; Krashen 1981; Gregg 1984). Nonetheless, the purpose of this study is to delve into the aspect of learners' perceptions of language learning and its relationship to the learners' process of language learning, whether conscious, unconscious, or something entirely different.

In a research by Ali, Amin and Khalid (2021), they conducted a quantitative study based on a survey design that examined the attitudes of Afghan Refugee students toward English and English language learning in Khyber Pakhtunkhwa (KPK), Pakistan, in order to determine their success rate and learning level. Through the census sampling technique, 38 participants were chosen from a population of all such students studying in various educational institutions throughout KPK. The information was gathered using a validated questionnaire based on five- 
point Likert scales and analysed using computer software, including Microsoft Excel and SPSS. It was discovered that, while they consider English to be the language of terrorist nations, they do not believe they should dislike it and stop learning it. The findings revealed that respondents have positive behavioural, cognitive, and emotional attitudes toward English and English language learning, which their teachers and parents should use to motivate them to speak English confidently, despite their fear of making mistakes and feeling shy.

Riadil (2020) discussed the student's perception of implementation issues and their solutions in Indonesia. The purpose of the study was to identify the speaking difficulties that EFL learners face when speaking English. The researcher used the qualitative research method for the study. Thirty-five students from Tidar University in Magelang provided data for the study. According to the findings of the study, the students were having difficulty learning to speak English. The most difficult issue for students was using their mother tongue in English class; 77 percent of students used their other language in English class, and 83 percent believed that their mother tongue was easier than English.

Besides that, Zulkefly and Razali (2019) looked into students' attitudes, particularly those who live in rural areas, which are known to have poor perceptions of and performance in learning the English language when compared to Malaysian students who live in urban areas. The study examines rural Malaysian students' attitudes toward learning English as a second language using Spolsky's (1989) Model of Second Language Learning and Gardner's (1985) Second Language Acquisition Theory. Their primary goal is to investigate the individual elements or factors that influence rural secondary school students' attitudes toward learning English. They discovered that two major factors influenced students' attitudes toward English learning: lessons that were not tailored to students' proficiency levels, interests, and students' individual reactions to negative and positive experiences.

Moreover, Kim and Garcia (2014) investigated the perceptions of 13 long-term ELLs about their schooling in the context of their school history, including programme placements, special education referral, and academic outcomes, in order to gain a better understanding of adolescent English language learners' (ELLs) educational experiences. Participants described themselves as English-proficient, motivated learners who found school to be both positive and challenging. The findings revealed a disparity between their postsecondary aspirations and academic performance, raising concerns about the adequacy of educational programmes and the identification of ELLs with disabilities.

\section{Methodology}

\section{Research Design}

The survey design was used in this study due to its strengths that are relevant to the purpose of this research. The survey questionnaire was developed by adopting the Foreign Language Attitude and Perceptions Survey (FLAPS) created by Sparks, Ganschow, and Javorsky (1993). The data needed to answer the research questions was collected from the survey questionnaire used.

\section{Research Setting}

This research was conducted at SK Lidong in Beluran district of Sabah. The school is a rural primary national school whereby the main medium of communication in the school is the 
national language, Bahasa Melayu. This school was chosen because the English language is rarely used by the local communities near the school, creating an environment that is similar to that of a foreign language. A study by Ler (2012) in Terengganu investigated cultural factors that affect the English proficiency level in rural areas. It was identified in the study's findings that the rural setting was the primary factor surrounding the problems that existed amongst the rural students. Therefore, this study was carried out in order to discover more information and insight into the correlation of rural settings towards English learning.

\section{Research Participants}

The respondents were drawn from a rural national primary school in Beluran, Sabah, where 27 upper primary students were selected for the research. The school has 14 Year 5 students and 13 Year 6 students. The ethnicities of the students are as follow Tidong (74.1\%), Sungai (11.1\%), Dusun (11.1\%), and Kadazan (3.7\%). The respondents had been exposed to English language learning from preschool to Year 6 as part of the Standard-based English Language Curriculum (KSSR). All respondents have English language proficiency levels ranging from low to above average.

\section{Research Instrument}

The data collection instrument in this study was a questionnaire. The questionnaire was made up of closed-ended questions. The surveys included closed-ended questions on the five-point Likert Scale. Moreover, Foreign Language Attitude and Perceptions Survey (FLAPS) created by Sparks, Ganschow, and Javorsky (1993) was modified and used to collect data from respondents. The instrument's twenty-three items were modified and divided into three dimensions: Language Attitudes (Section B), which investigates students' attitudes/motivation, attentiveness, anxiety, and self-confidence in the second language classroom, and Language Academic Skills (Section C), which investigates students' opinions of their language skills in relation to second language learning and tests. The instrument consisted of Likert-scale questions (ranging from 1 to 5 ) administered in a forced-choice format, with respondents instructed to select one of five options: (1) strongly agree, (2) agree, (3) neutral, (4) disagree, and (5) strongly disagree. Respondents were also asked to provide demographic information such as age, gender, and ethnicity in Section A of the questionnaire. The questionnaire was also constructed in dual languages (Malay and English). This is because the researcher considered the participants' English proficiency level that ranged from low to above average. Thus, it was understood that they would not be able to answer the items efficiently if they were not able to understand the items well enough. Hence, the duality of the items' language makes it easier for the research participants to read, understand and answer truthfully.

\section{Data Collection Procedures}

The survey in this study is supported by data gathered through the distribution of the questionnaire. The distribution was done online (Google Form). This is due to the state of the education system, which has been impacted by the Covid-19 pandemic. The researcher sought approval from the school before beginning the research. Once approval was obtained, the researcher gave the participants a brief overview of the research's objectives and focus. The identities of the participants were kept anonymous in order to protect them. The researcher reached out to the respondents by personally contacting them via WhatsApp. The online questionnaire included a brief explanation of the survey's objectives as well as an item 
overview. The researcher generated a link for the form and sent it to the respondents. Respondents were given two days to complete the form in order to accommodate their time and work constraints.

\section{Data Analysis Method}

Data analysis methods differ depending on whether the data is qualitative or quantitative. The purpose of quantitative data analysis is to examine the statistical relationship. In contrast, qualitative data analysis needs researchers to make meaning of the text imagery in order to generate solutions to their research questions (Creswell, 2002). The items from the questionnaire were analysed using a program which is the Statistical Package for the Social Science (SPSS) software platform. The questionnaire data was analysed using descriptive statistics, specifically frequency analysis. The percentages of responses and frequency level were calculated. This is because the research questions require answers based on the analysis of the data from the questionnaire. Therefore, the learners' responses to their perceptions of language attitudes and language academic skills in SLL were examined using frequency analysis. The analysis looks at the frequency of the Likert Scale whereby each aspect such as "Strongly Agree" to "Strongly Disagree" were critically analysed by the researcher to perceive the highest frequency, the lowest, or any interesting factors that might contribute to the analysis of each item.

\section{Findings}

The pertinent research questions of this research, in essence, investigate the rural students' language attitudes in learning English and how they perceive their progress of language academic skills in the English language. Therefore, the survey was conducted in order to obtain information on these two major research questions by evaluating the frequency of each item from the value of 1 (strongly agree) to the value of 5 (strongly disagree).

\section{Research Question 1}

What are the students' perceptions towards second language learning as related to language attitudes in SK Lidong?

The following table below shows the tabulated data that reveals the students' perception towards SLL as related to language attitude. For this section, there were 14 items that focused on the students' needs, feelings, and behaviours in regards to their language learning

Table 1: Students' Perception on Language Attitudes

\begin{tabular}{lllllll}
\hline No. Question Items & $\begin{array}{l}\text { Strongly } \\
\text { Agree }\end{array}$ & Agree & Neutral & Disagree & $\begin{array}{l}\text { Strongly } \\
\text { Disagree }\end{array}$ \\
\hline 1. & $\begin{array}{l}\text { I feel I have spent too much time } \\
\text { studying my English language. }\end{array}$ & $3.7 \%$ & $14.8 \%$ & $3.7 \%$ & $63 \%$ & $14.8 \%$ \\
\hline $2 . \quad \begin{array}{l}\text { I feel I should have studied } \\
\text { harder for my English language. }\end{array}$ & $77.8 \%$ & $14.8 \%$ & 0 & $3.7 \%$ & $3.7 \%$ \\
\hline $3 . \quad \begin{array}{l}\text { I have not gotten nervous and } \\
\text { tense when studying my English } \\
\text { language. }\end{array}$ & $25.9 \%$ & $25.9 \%$ & $3.7 \%$ & $37 \%$ & $7.4 \%$ \\
\hline $4 . \quad \begin{array}{l}\text { I do not worry about my English } \\
\text { language subject. }\end{array}$ & $14.8 \%$ & $11.1 \%$ & $3.7 \%$ & $63 \%$ & $7.4 \%$ \\
\hline
\end{tabular}




\begin{tabular}{|c|c|c|c|c|c|c|}
\hline 5. & $\begin{array}{l}\text { I do not feel capable of studying } \\
\text { for my English language subject. }\end{array}$ & $11.1 \%$ & $11.1 \%$ & 0 & $59.3 \%$ & $18.5 \%$ \\
\hline 6. & $\begin{array}{l}\text { I am more easily distracted } \\
\text { when I study my English } \\
\text { language subject than my other } \\
\text { subjects. }\end{array}$ & $7.4 \%$ & $11.1 \%$ & 0 & $51.9 \%$ & $29.6 \%$ \\
\hline 7. & $\begin{array}{l}\text { I feel I fall asleep more easily in } \\
\text { my English language class than } \\
\text { my other classes. }\end{array}$ & $3.7 \%$ & $3.7 \%$ & 0 & $63 \%$ & $29.6 \%$ \\
\hline 8. & $\begin{array}{l}\text { I feel my attention wanders } \\
\text { more easily in my English } \\
\text { language class than my other } \\
\text { classes. }\end{array}$ & $7.4 \%$ & $7.4 \%$ & 0 & $63 \%$ & $22.2 \%$ \\
\hline 9. & $\begin{array}{l}\text { I feel nervous and afraid about } \\
\text { participating in a class } \\
\text { discussion during my English } \\
\text { language class. }\end{array}$ & $7.4 \%$ & $7.4 \%$ & 0 & $70.4 \%$ & $14.8 \%$ \\
\hline 10. & $\begin{array}{l}\text { I feel that I am not in control of } \\
\text { my grades in my English } \\
\text { language subject. }\end{array}$ & $51.9 \%$ & $25.9 \%$ & 0 & $7.4 \%$ & $14.8 \%$ \\
\hline 11. & $\begin{array}{l}\text { I feel anxious about English } \\
\text { language exams. }\end{array}$ & $63 \%$ & $18.5 \%$ & $3.7 \%$ & $7.4 \%$ & $7.4 \%$ \\
\hline 12. & $\begin{array}{l}\text { I want to learn the English } \\
\text { language. }\end{array}$ & $85.2 \%$ & $11.1 \%$ & $3.7 \%$ & 0 & 0 \\
\hline 13. & $\begin{array}{l}\text { I define being successful in my } \\
\text { English language subject as an A } \\
\text { scale. }\end{array}$ & $14.8 \%$ & $7.4 \%$ & $7.4 \%$ & $59.3 \%$ & $11.1 \%$ \\
\hline 14. & $\begin{array}{l}\text { I will never be successful in my } \\
\text { English language subject. }\end{array}$ & $3.7 \%$ & $3.7 \%$ & $3.7 \%$ & $63 \%$ & $25.9 \%$ \\
\hline
\end{tabular}

It was revealed that $77.8 \%$ (63\% disagreed and $14.8 \%$ strongly disagreed) of the students did not spend much of their time in learning the English language. It was further strengthened with the fact that $92.6 \%$ ( $77.8 \%$ strongly agreed and $14.8 \%$ agreed) of the students felt like they need to put more effort into studying the English language. This denoted that the majority of the students realised that they did not spend enough time studying the target language, but at the same time, they were aware of the need to be more studious for the subject.

Next, the item "I have not gotten nervous and tense when studying my English language" received nearly balanced scores for those that leaned towards strongly disagreed and strongly agreed. It could be seen that $51.8 \%$ (25.9\% strongly agreed and $25.9 \%$ agreed) of the students did not get nervous and tense when studying the language. On the other hand, $44.4 \%$ (37\% disagreed and 7.4 strongly disagreed) of the students felt nervous and tense when they were studying for the English language, while $3.7 \%$ of the students had a neutral view of this matter. This revealed that slightly more than half of the students did not get nervous and tense whenever they study the target language. This positively conveyed that most of the students were able to learn in a lowered affective filter environment. 
Consequently, this matter can be clarified by looking at the frequency for the item "I do not worry about my English language subject," whereby the majority of the students, which was at $70.4 \%$ (63\% disagreed and $7.4 \%$ strongly disagreed) of the respondents opposed this notion. This shows that more than half of the students were worried about the English language subject. Furthermore, $77.8 \%$ (59.3\% disagreed and $18.5 \%$ ) of the students voted to go against this notion of "I do not feel capable of studying for my English language subject". Meanwhile, only $22.2 \%$ ( $11.1 \%$ strongly agreed and 11.1 agreed) of the respondents felt that they were capable of studying for the English language subject. The three items (3rd, 4th, and 5th) are correlated to one another, which augmented the data that half of the students feel tense and nervous (51.8\%), the majority of them were worried $(70.4 \%)$, and they did not feel capable of studying $(77.8 \%)$ in regards to the learning of the target language.

The 6th to 9th items of the section for language attitude are relevant to the teaching and learning process of the English language in a formal setting. The item "I am more easily distracted when I study my English language subject than my other subjects" got a high frequency of $81.5 \%$ ( $51.9 \%$ disagreed and $29.6 \%$ strongly disagreed). Meanwhile, there was a low frequency of $18.5 \%$ ( $7.4 \%$ strongly agreed and $11.1 \%$ agreed) amongst the respondents that agreed with the item's statement. This divulged that the majority of the students did not get easily distracted when they were studying the English language subject compared to their other subjects. Next, there was a very high frequency of $92.6 \%$ (63\% disagreed and $29.6 \%$ strongly disagreed) for the item "I feel I fall asleep more easily in my English language class than my other classes". The remainder of the respondents $(7.4 \%$, i.e., $3.7 \%$ strongly agreed and $3.7 \%$ agreed) felt that they tend to fall asleep more easily in the English language class compared to their other classes.

Moreover, the attentiveness of the respondents during the English language teaching and learning sessions is disclosed through the fact that $85.2 \%$ (63\% disagreed and $22.2 \%$ strongly disagreed) of the students disagreed with the notion "I feel my attention wanders more easily in my English language class than my other classes". In comparison, $14.8 \%$ (7.4\% strongly agreed and $7.4 \%$ agreed) of them stand to the fact that they were not able to focus in their English language class than their other classes. It is further revealed that the data for the item "I feel nervous and afraid about participating in a class discussion during my English language class" showed $85.2 \%$ ( $70.4 \%$ disagreed and $14.8 \%$ strongly disagreed) of the students did not feel nervous and afraid for joining in the class discussion meanwhile, $14.8 \%$ (7.4\% strongly agreed and $7.4 \%$ agreed) of the students conveyed the fact that they did get nervous and afraid in participating class discussion. Essentially, the majority of the respondents have a positive perception of their learning process of the English language in a formal setting.

It was found that the item "I feel that I am not in control of my grades in my English language subject" got a frequency of $77.8 \%$ (51.9\% strongly agreed and $25.9 \%$ agreed) from the respondents. On the other hand, $22.2 \%$ ( $7.4 \%$ disagreed and $14.8 \%$ strongly disagreed) of the students felt that they were in control of their English language subject's grade. This revealed that most of the students were not confident of their ability in achieving certain grades for their English language subject. Apart from that, 81.5\% (63\% strongly agreed and $18.5 \%$ agreed) of the students agreed to the "I feel anxious about English language exams" item with $14.8 \%$ (7.4\% disagreed and $7.4 \%$ strongly disagreed) of the respondents who did not feel anxious for their language exams. It is clear that the high frequency of $77.8 \%$ for those that 
felt they were not in control of their grades is interrelated to the high frequency of $81.5 \%$ that felt anxious for their language exam.

Interestingly, the data also revealed a high frequency of students who agreed to the statement "I want to learn the English language" at 96.3\% (85.2\% strongly agreed and $11.1 \%$ agreed). On the other hand, the balance of $3.7 \%$ chose to be neutral on this matter. This showed that none of the respondents disagreed with the fact that they want to learn the English language. Hence, they all showed a positive response to having the readiness and learning the target language. Nevertheless, they did not emphasise getting the grade A to define their success in the target language. This is displayed through the data that $70.4 \%$ (59.3\% disagreed and 11.1 strongly disagreed) of the respondents disagreed with the "I define being successful in my English language subject as an A scale" item while $22.2 \%$ (14.8\% strongly agreed and $7.4 \%$ agreed) of them agreed to the fact that they need to score the $A$ grade to validate their success in the English language subject. Contrastingly, the item "I will never be successful in my English language subject" received agreement at the frequency of $88.9 \%$ (63\% agreed and $25.9 \%$ strongly agreed) from the respondents, with the remainder of them at $11.1 \%$ (3.7\% strongly agreed, $3.7 \%$ agreed, and $3.7 \%$ neutral). This exhibited the students' negative perception that they will never be able to be successful in the subject.

\section{Research Question 2}

What are the students' perceptions towards second language learning as related to language academic skills in SK Lidong?

Subsequently, in order to further elucidate the understanding from the data revealed for students' perception of language attitude, Table 4.2 uncovers the students' perception towards SLL as related to language academic skills. The students' language attitude has an intricate relationship with their English proficiency level. Thus, the following table shows the findings based on their view of their language academic skills in the English language.

Table 2: Students' Perception on Language Academic Skills

\begin{tabular}{|c|c|c|c|c|c|c|}
\hline No. & Question Items & $\begin{array}{l}\text { Strongly } \\
\text { Agree }\end{array}$ & Agree & Neutral & Disagree & $\begin{array}{l}\text { Strongly } \\
\text { Disagree }\end{array}$ \\
\hline 1. & $\begin{array}{l}\text { I learn the vocabulary of the } \\
\text { English language easily. }\end{array}$ & $25.9 \%$ & $14.8 \%$ & $7.4 \%$ & $40.7 \%$ & $11.1 \%$ \\
\hline 2. & $\begin{array}{l}\text { I have difficulty spelling words } \\
\text { in an English language class. }\end{array}$ & $22.2 \%$ & $48.1 \%$ & $3.7 \%$ & $11.1 \%$ & $14.8 \%$ \\
\hline 3. & $\begin{array}{l}\text { I learn the rules of grammar in } \\
\text { my English language class } \\
\text { easily. }\end{array}$ & $14.8 \%$ & $22.2 \%$ & 0 & $51.9 \%$ & $11.1 \%$ \\
\hline 4. & $\begin{array}{l}\text { I have difficulty in } \\
\text { conversing/speaking in the } \\
\text { English language. }\end{array}$ & $63 \%$ & $11.1 \%$ & 0 & $7.4 \%$ & $18.5 \%$ \\
\hline 5. & $\begin{array}{l}\text { I write in the English language } \\
\text { easily. }\end{array}$ & $18.5 \%$ & $7.4 \%$ & $3.7 \%$ & $48.1 \%$ & $22.2 \%$ \\
\hline 6. & $\begin{array}{l}\text { I have difficulty in translating } \\
\text { the English language into my } \\
\text { first language. }\end{array}$ & $55.6 \%$ & $18.5 \%$ & 0 & $14.8 \%$ & $11.1 \%$ \\
\hline
\end{tabular}




\begin{tabular}{lllllll}
\hline 7. I have difficulty in listening to $55.6 \%$ & $11.1 \%$ & $11.1 \%$ & $7.4 \%$ & $14.8 \%$ \\
and understanding the English \\
language as it is spoken.
\end{tabular}

The first item of this section examines vocabulary skill or knowledge in the English language whereby the item stated, "I learn the vocabulary of the English language easily". The table revealed that $51.8 \%$ (40.7\% disagreed and $11.1 \%$ strongly disagreed) of the students considered that the English language vocabulary learning process is easy. In comparison, $40.7 \%$ (25.9\% strongly agreed and $14.8 \%$ agreed) of them thought otherwise. However, the learning process of the vocabulary in the English language did not mean that it would coincide with the data for the "I have difficulty spelling words in an English language class" item. This is because the frequency for the item is at $70.3 \%$ (22.2\% strongly agreed and $48.1 \%$ agreed) for students that have difficulty in spelling words in the English language class, while $25.9 \%$ (11.1\% disagreed and $14.8 \%$ strongly disagreed) of the respondents showed the confidence to spell the words in an English language class.

It is unveiled that $63 \%$ ( $51.9 \%$ disagreed and $11.1 \%$ strongly disagreed) of the students disagreed with the "I learn the rules of grammar in my English language class easily" item with the differing position of $37 \%$ ( $14.8 \%$ strongly agreed and $22.2 \%$ agreed) frequency for students that were able to learn the rules of the grammar easily. This shows that more than half of the respondents were not able to learn the rules of grammar in the English language class easily.

The next finding revealed the students' speaking skills in the English language. The data indicated that $74.1 \%$ (63\% strongly agreed and $11.1 \%$ agreed) of the students admitted to the fact that they were not able to converse or speak in the target language. The item "I have difficulty in conversing/speaking in the English language" also revealed that only $25.9 \%$ (7.4\% disagreed and $18.5 \%$ strongly disagreed) of the respondents believe in themselves in terms of their ability to speak or converse in the English language.

Besides speaking skills, the data also displayed the students' perception of their writing skills in the English language. A total of $70.3 \%$ (48.1\% disagreed and $22.2 \%$ strongly disagreed) of the students disagreed with the "I write in the English language easily" item. Meanwhile, $25.9 \%$ ( $18.5 \%$ strongly agreed and $7.4 \%$ agreed) of the students have confidence in being able to write in the English language easily. It is also revealed that $25.9 \%$ (14.8\% agreed and $11.1 \%$ strongly agreed) of the respondents agreed to the "I have difficulty in translating the English language into my first language". These two similar percentages might have a correlation, whereby the students who could write in the English language easily should have no difficulty translating the language into their first language. On the other hand, $74.1 \%$ (55.6\% strongly agreed and $18.5 \%$ ) of the students did not have the ability to translate the target language into their first language easily. 
The "I have difficulty in listening to and understanding the English language as it is spoken" item disclosed the students' perception of their listening skills. The number of students who have confidence in their ability to listen and understand the target language easily is quite low compared to those with difficulty in it. For instance, $66.7 \%$ (55.6\% strongly agreed and $11.1 \%$ agreed) of the students agreed to the fact that they were not able to listen and understand the English language as it is spoken. In comparison, only $22.2 \%$ (7.4\% disagreed and $14.8 \%$ strongly disagreed) of the respondents could listen and understand the target language as it is spoken.

Besides that, the item "I translate from my first language into the English language easily" received a high frequency of disagreement of $77.8 \%$ (59.3\% disagreed and $18.5 \%$ strongly disagreed). This means that more than half of the students were not capable of translating their first language into the English language easily. It shows that their proficiency in the target language is quite dismal compared to their first language. However, $22.2 \%$ (14.8\% strongly agreed and $7.4 \%$ agreed) of the students showed that they could easily translate their first language into the English language.

Last but not least, the students' reading skills could be gleaned from the data revealed in the last item, "I read in my English language class easily". The data disclosed a positive contradiction to their other data of the other skills whereby for reading skill, $77.8 \%$ (25.9\% strongly agreed and $51.9 \%$ agreed) of the students agreed to the fact that they were able to read in the English language easily. In comparison, only $11.1 \%$ strongly disagreed, which means they were not able to read in the target language easily.

\section{Discussion}

The findings unearthed from the data revealed in the two tables revealed information and insights to elucidate on the rural students' perception in regards to their language attitude and language academic skills in the English language. Most of the students are aware of the need to study the English language harder because they knew that they did not spend much time studying it. Their lives in the rural area affected their quality of education, whereby they were not exposed to English multimedia (Mat \& Yunus, 2014). They might have spent their time helping out their parents with house chores or farm work. Additionally, it was clear that the learners did not acquire English as their second language because they either learn their ethnic language, such as Tidong language first, then Bahasa Melayu or vice versa. This indicates that the parents would not communicate with their children in the English language at home and prefer to use their mother tongue as a medium of communication. Thus, the pupils did not spend time learning the subject because they lacked the time and resources.

It is also revealed that most of them experienced anxiety, nervousness and tenseness in studying the target language. However, they showed a positive attitude and readiness in learning the language in a formal setting. Most of their negative feelings are rooted in their lack of confidence and awareness of their low English proficiency level. This type of student has an instinctual fear of failure whereby they are afraid of being degraded or judged by their peers (Jackson, 2017). Nonetheless, the teacher was able to conduct a fun learning environment for the students in the classroom because the majority of them, despite being low-proficient students, still displayed learning readiness and excitement to learn the subject. A fun learning environment can impact SLL in the classroom to be more effective (Stoimcheva- 
Kolarska, 2020). This denoted that the teacher was able to lower the learners' affective filter during the teaching and learning process and encouraged them to be more susceptible to the teaching and learning content.

The fact that the data revealed the respondents' perception of not being able to be successful in the subject is further illuminated by their perception of their language academic skills whereby most of them are not confident of the rudimentary language skills such as listening, speaking and writing excluding the reading skill. The majority of the students showed great confidence in their reading skills because more than half of them chose to agree with the notion that they were able to read easily in the English language. Thus, the findings showed that the correlation between rural areas, language attitude and language academic skills exist. As a result, the study is able to provide some insights into the learners' rural background affecting their target language learning process and how it contributes to their perception of language attitude and language academic skills.

\section{Implications}

The crucial aspect that needs to be addressed in this study is the research context whereby the research was conducted with participants from a rural area. One of the major themes in developing-country literature is the rural disadvantage in educational quality. Existing literature on school location in developing countries has discovered lower academic achievement in rural schools (Webster \& Fisher, 2000; Young, 1998). This could be due to a lack of educational resources in those schools, such as facilities, instructional materials, teacher quality, and teacher supply, which affects teacher effectiveness (Levira, 2000; Stephens, 1991; Vegas, 2007). According to Vegas (2007), working conditions in urban schools are much better in most developing countries (Charil, 1997; Hanushek, 1997; Sammons, 1999; Vegas 2007). Therefore, the standards of analysing the whole research could not be on par with the research conducted with students from urban schools. Certain aspects such as the setting, research participants' backgrounds and culture must be considered in order to develop an effective and authentic investigation. As indicated through the research findings, the students' willingness to learn the English language subject is quite positive despite their low proficiency level of the language. Therefore, the implication to this matter is the teacher should construct the lesson by integrating scaffolding such as code-switching or GrammarTranslation Method while ensuring the content conforms to the suggestion stated in Krashen's input hypothesis. The teaching and learning content should be modified to accommodate the learners' proficiency level, and for those that cannot understand English, scaffolding should be practised. Gradually, when the students are able to advance in their language learning process, according to Modupeola (2013); Meyer (2008), scaffolding can be lessened.

Another implication from the findings is to promote collaborative learning amongst peers. The finding revealed that some students showed positive responses for the language academic skills, which means some students have an adequate level of mastery in their language academic skills. Thus, the students should work collaboratively with their peers in order to improve their language skills. Hence, the teacher should include more group work in the lessons to allow interaction amongst the students in the classroom. 
The educational quality in the rural areas needs more research, but this study provided enough insights into the education quality experienced by the research participants. The progress of the educational system is currently in line with the Malaysian educational aspirations to produce holistic and progressive individuals for the country's advancement. However, complications such as the slow development of schools in rural areas are a pressing issue that should be dealt with to achieve the country's aspiration thoroughly. Therefore, this study provides insights for people to be more aware of the rural students' issue in the SLL based on the data for the perception of the language attitude and language academic skills obtained through the survey.

\section{Conclusion}

Conclusively, this study set out to investigate the perception of the students from a rural school. The two major aspects that were encapsulated in this research were language attitude and language academic skills that were theoretically conceptualised through the perspectives of Krashen's Natural Approach, specifically the affective filter hypothesis and the input hypothesis. The status of the English language in Malaysia had been progressively and constantly changing throughout the years from the Pre-Independence, Post-Independence, and the current 21st century. The importance of the language was proven to be essential across the globe, whether for the purpose of education, economy, politics, or social. However, the development of the language in an educational context has not seen an agreeable balance between the schools in Malaysia's urban and rural areas.

Therefore, the findings in this study brought significant insights into how the rural learners perceive the English language in SLL and the extent of their language academic skills. This information is crucial in order to create awareness of the educational quality in rural schools. Most importantly, this research assists in understanding individual elements that contribute to the rural students' attitudes towards learning the English language. By understanding these elements, researchers, teachers, administrators, and other stakeholders will be able to understand the reason behind the rural students' positive and negative attitudes when learning the English language, and this information is fundamental in providing equality in education quality for SLL. Equality in educational quality for SLL is quintessential in ensuring the growth of competent English language learners that can thrive in this era of technology and communication.

To summarise, this study provides new insight on the topic of rural primary school students' perceptions of experiences towards SLL, and it will indubitably be of tremendous use to teachers and pupils in the future, specifically in the teaching and learning of English. It is recommended that the teachers adjust classroom pedagogy to meet the needs and proficiency levels of the students, and the government should prioritise infrastructure development and resources for rural schools.

\section{References}

Ali, S. S., Amin, T., \& Khalid, S. (2021). Analysis of the Afghan Refugee Students' Attitudes towards English language and English Language Learning: A Case Study of KPK, Pakistan. Ilkogretim Online, 20(5). 
Aruna, P. (2014). No emphasis and poor teachers the causes, say employers. The Star, 11. http://www.thestar.com.my/News/Nation/2014/12/11/Fresh-graduates-strugglingNo-emphasis-and-poor-teachers-the-causes-say-employers/ [11 June 2021]

August, D. E., \& Shanahan, T. E. (2006). Developing literacy in second-language learners: Report of the National Literacy Panel on Language-Minority Children and Youth. Lawrence Erlbaum Associates Publishers.

Azman, H. (2016). Implementation and challenges of English language education reform in Malaysian primary schools. 3L: Language, Linguistics, Literature ${ }^{\circledR}, 22(3)$.

Bartram, B. (2010). Attitudes to Language, insights from comparative education. London: Continuum.

Bell, S. (2013). Learning with information systems: Learning cycles in information systems development. Routledge.

Bialystok, E. (1978). A theoretical model of second language learning 1. Language learning, 28(1), 69-83.

Brown, H. D. (2000). Principles of language learning and teaching (Vol. 4). New York: Longman.

Charil, M. (1997). Kajian sekolah berkesan di Malaysia. Unpublished doctoral dissertation). Universiti Kebangsaan Malaysia: Bangi.

Creswell, J. W. (2012). Educational Research: Planning, Conducting and Evaluating Quantitative and Qualitative Research. Massachusetts: Pearson.

Delpit, L. (1995). Other people's children: Cultural conflict in the classroom. Harvard educational review, 65, 510-510.

Don, Z. M., Abdullah, M. H., Abdullah, A. C., Lee, B. H., Kaur, K., Pillai, J., \& Hooi, M. Y. (2015). English language education reform in Malaysia: The Roadmap 2015-2025. Putrajaya: Ministry of Education.

Du, X. (2009). The affective filter in second language teaching. Asian Social Science, 5(8), 162165.

EF EPI. (2020) - EF English Proficiency Index. 2020. https://www.ef.com/wwen/epi/ [12 June 2021].

Ehrman, M. E. (1996). Understanding second language learning difficulties. Sage.

Ellis, R., \& Shintani, N. (2014). Exploring Language Pedagogy through Second Language Acquisition Research. Oxon: Routledge.

Engkasan, S. B., \& Yamat, H. (2021). English Language Learning Experience Among Iban Secondary ESL learners in A Rural Area. Journal of English Language Teaching and Applied Linguistics, 3(3), 59-65.

Gajalakshmi. (2013). High School Students' Attitude towards learning English language. International journal of scientific and Research publications, 3(9):pp1-7

Gardner, R. C. (1985). Social psychology and second language learning: The role of attitudes and motivation. Arnold.

Gass, S. M., \& Mackey, A. (2007). Input, interaction, and output in second language acquisition. Theories in second language acquisition: An introduction, 175(199), 40.

Gelman, S. A., Croft, W., Fu, P., Clausner, T., \& Gottfried, G. (1998). Why is a pomegranate an apple? The role of shape, taxonomic relatedness, and prior lexical knowledge in children's overextensions of apple and dog. Journal of Child language, 25(2), 267-291.

Ghazali, S. N. (2016). Learner background and their attitudes towards studying literature. Malaysian Journal of ELT research, 4(1), 17. 
Gill, R. S. (2014). Enhancing English teacher language proficiency: the Malaysian experience. http://www.britishcouncil.or.th/sites/britishcouncil.th/files/dr.ranjit.pdf $\left[\begin{array}{ll}13 & \text { June }\end{array}\right.$ 2021].

Gobel, P., Thang, S. M., Sidhu, G. K., Oon, S. I., \& Chan, Y. F. (2013). Attributions to success and failure in English language learning: A comparative study of urban and rural undergraduates in Malaysia. Asian Social Science, 9(2), 53.

Gregg, K. R. (1984). Krashen's monitor and Occam's razor. Applied linguistics, 5(2), 79-100.

Halliday, M. A. K., \& Martin, J. R. (1993). Writing science: Literacy and discursive power. London: Falmer (Critical Perspectives on Literacy and Education). Pittsburgh: University of Pittsburgh Press.

Hanushek, E. A. (1997). Assessing the effects of school resources on student performance: An update. Educational evaluation and policy analysis, 19(2), 141-164.

Herzog, M. J. R., \& Pittman, R. B. (1995). Home, family, and community: Ingredients in the rural education equation.

Jackson, C. (2017). Fear of failure. In Understanding Learning and Motivation in Youth (pp. 3039). Routledge.

Jafar, O. F. (2015). Format baharu UPSR bantu kuasai bahasa Inggeris. BHOnline. https://origin.bharian.com.my/kolumnis/2015/09/85367/format-baharu-upsr [11 June 2021]

Jalleh, J. (2013). Majority of teachers not proficient in English. The Star Online. http://www.thestar.com.my/News/Nation/2012/09/26/Majority-of-teachersnot-proficient-in-English/ [11 June 2021]

Johnson, J., \& Strange, M. (2005). Why rural matters 2005: The facts about rural education in the 50 states. Rural School and Community Trust.

Kim, W. G., \& García, S. B. (2014). Long-term English language learners' perceptions of their language and academic learning experiences. Remedial and Special Education, 35(5), 300-312.

Kormos, J. (2016). The second language learning processes of students with specific learning difficulties. Taylor \& Francis.

Krashen, S. (1992). The input hypothesis: An update. Linguistics and language pedagogy: The state of the art, 409-431.

Krashen, S. D. (1981). Second language acquisition and second language learning. University of Southern California.

Krashen, S. D. (1985). The input hypothesis: Issues and implications. Addison-Wesley Longman Limited.

Krashen, S. D., \& Krashen, S. D. (1983). Natural approach. New York: Pergamon.

Levira, M. A. (2000). Instructional resources as a factor in educational performance: A case study in Tanzania (Doctoral dissertation, Concordia University).

Levy, P. S., \& Lemeshow, S. (2013). Sampling of populations: methods and applications. John Wiley \& Sons.

Loo, S. P. (2007). Schooling in Malaysia. Going to school in East Asia, 201-232.

Macaro, E. (2018). English medium instruction. Oxford University Press.

Macaro, E., Curle, S., Pun, J., An, J., \& Dearden, J. (2018). A systematic review of English medium instruction in higher education. Language Teaching, 51(1), 36-76.

Mat, S. S. C., \& Yunus, M. M. (2014). Attitudes and motivation towards learning English among FELDA school students. Australian Journal of Basic and Applied Sciences, 8(5), 1-8.

McIntyre, L. J. (1998). Practical Skeptic. Mayfield Publishing Company. 
Meyer, H. (2008). The pedagogical implications of L1 use in the L2 classroom. Maebashi Kyoai Gakuen College Ronsyu, 8(147-159).

Ministry of Education Malaysia. (1988). National education philosophy. Kuala Lumpur: Curriculum Development Centre.

Ministry of Education Malaysia. (2013). Laporan Awal. Pelan Pembangunan Pendidikan Malaysia, 2025.

Modupeola, O. R. (2013). Code-Switching as a teaching strategy: Implication for English Language teaching and learning in a multilingual society. IOSR Journal of Humanities and Social Science, 14(3), 92-94.

Othman, M., \& Muijs, D. (2013). Educational quality differences in a middle-income country: the urban-rural gap in Malaysian primary schools. School Effectiveness and School Improvement, 24(1), 1-18.

Pilgreen, J. (2006). Supporting English learners: Developing academic language in the content area classroom. Supporting the literacy development of English learners, 41-60.

Rashid, R. A. (2016). Topic continuation strategies employed by teachers in managing supportive conversations on Facebook Timeline. Discourse Studies, 18(2), 188-203.

Rashid, R. A., Vethamani, M. E., \& Rahman, S. B. A. (2010). Approaches Employed by Teachers in Teaching Literature to Less Proficient Students in Form 1 and Form 2. English Language Teaching, 3(4), 87-99.

Riadil, I. G. (2020). A Study of Students' Perception: Identifying EFL Learners' Problems in Speaking Skill. International Journal of Education, Language, and Religion, 2(1), 31-38.

Rutherford, W. E., \& Smith, M. S. (1985). Consciousness-raising and universal grammar. Applied linguistics, 6(3), 274-282.

Salant, P., Dillman, I., \& Don, A. (1994). How to conduct your own survey (No. 300.723 S3.).

Salleh, F. I. M., Ghazali, J. M., Ismail, W. N. H. W., Alias, M., \& Rahim, N. S. A. (2020). The impacts of COVID-19 through online learning usage for tertiary education in Malaysia. Journal of Critical Reviews, 7(8), 147149.

Sammons, P. (1999). School effectiveness: Coming of age in the 21st century. Management in Education, 13(5), 10-13.

Schleppegrell, M. J., \& Colombi, M. C. (Eds.). (2005). Developing advanced literacy in first and second languages: Meaning with power. Routledge.

Schmidt, R. W. (1990). The role of consciousness in second language learning1. Applied linguistics, 11(2), 129-158.

Seliger, H. W. (1983). The language learner as linguist: Of metaphors and realities. Applied linguistics, 4(3), 179-191.

Sparks, R. L., Ganschow, L., \& Javorsky, J. (1993). Perceptions of low and high risk students and students with learning disabilities about high school foreign language courses. Foreign Language Annals, 26(4), 491-510.

Spolsky, B. (1989). Communicative competence, language proficiency, and beyond. Applied Linguistics, 10(2), 138-156.

Stephens, D. (1991). The quality of primary education in developing countries: who defines and who decides?. Comparative education, 27(2), 223-233.

Stoimcheva-Kolarska, D. L. (2020). The Impact of a Relaxed and Fun Learning Environment on the Second Language Learning. Online Submission, 2(1), 9-17.

Vegas, E. (2007). Teacher labor markets in developing countries. The future of children, 219232. 
Wächter, B., \& Maiworm, F. (Eds.). (2014). English-taught programmes in European higher education: The state of play in 2014. Lemmens Medien $\mathrm{GmbH}$.

Webster, B. J., \& Fisher, D. L. (2000). Accounting for variation in science and mathematics achievement: A multilevel analysis of Australian data Third International Mathematics and Science Study (TIMSS). School Effectiveness and School Improvement, 11(3), 339360.

White, L. (1987). Against comprehensible input: the input hypothesis and the development of second-language competence1. Applied linguistics, 8(2), 95-110.

Young, M. F. (1998). The curriculum of the future: from the" new sociology of education" to a critical theory of learning. Psychology Press.

Zhou, M., \& Xiaomei, W. (2017). Introduction: Understanding language management and multilingualism in Malaysia. International journal of the sociology of language, 207(244), 1-16.

Zulkefly, F., \& Razali, A. B. (2019). Malaysian Rural Secondary School Students' Attitudes towards Learning English as a Second Language. International Journal of Instruction, 12(1), 1141-1156. 
English Language Learning Attitudes and Perceptions Inventory (Inventori Sikap dan Persepsi Pembelajaran Bahasa Inggeris) This inventory is divided into three sections.

Section A: Background Information

Section B: English Language Learning Attitudes

Section C: English Language Academic Perceptions

Inventori ini terbahagi kepada tiga bahagian.

Bahagian A: Maklumat Latarbelakang

Bahagian B: Sikap Pembelajaran Bahasa Inggeris

Bahagian C: Persepsi Akademik Pembelajaran Bahasa Inggeris

* Required

1. 1. Sex (Jantina) *

Mark only one oval.

Male

Female

2. 2. Age (Umur) *

Mark only one oval.

9 years old

10 years old

11 years old

12 years old 
3. 3. Race/Etnicity (Bangsa/Etnik) *

Mark only one oval.
$\bigcirc$ Kadazan
Dusun
Tidong
$\bigcirc$ Sungai
Murut
Other:

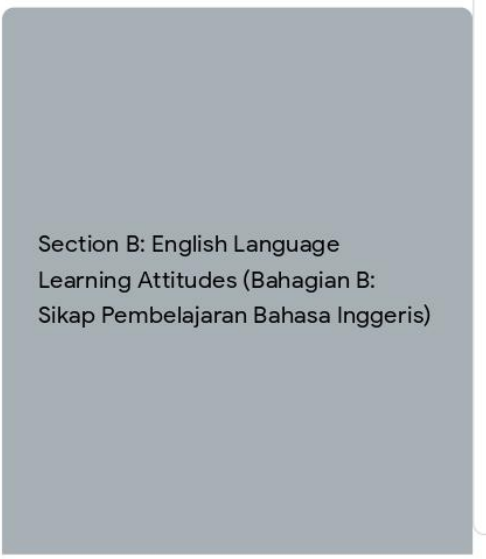

\section{Instructions:}

Below are question items that assess your attitudes and perceptions concerning English language learning. Read each statement and then decide if you:

(1) Strongly Agree; (2) Agree; (3) Neutral; (4) Disagree; or (5) Strongly Disagree.

There are no right or wrong answers. We are simply interested in your opinions. Select your answers in the appropriate boxes.

Arahan:

Di bawah ini terdapat item-item soalan untuk menilai sikap dan persepsi anda terhadap pembelajaran bahasa Inggeris. Baca setiap pernyataan dan kemudian tentukan sama ada anda:

(1) Sangat Setuju; (2) Setuju; (3) Neutral; (4) Tidak Setuju; atau (5) Sangat Tidak Setuju.

Tidak terdapat jawapan betul atau salah. Kami hanya berminat terhadap pandangan anda. Tandakan jawapan anda dalam kotak yang berkenaan.

4. 1. I feel I have spent too much time studying my English language. (Saya merasakan saya telah menghabiskan terlalu banyak masa untuk mempelajari bahasa Inggeris.) *

Mark only one oval.

$\begin{array}{lllll}1 & 2 & 3 & 4 & 5\end{array}$

(ㄱ) Strongly Agree (Sangat Setuju) $\square \odot \odot$ Strongly Disagree (Sangat Tidak Bersetuju)

5. 2. I feel I should have studied harder for my English language. (Saya rasa saya sepatutnya belajar dengan lebih bersungguh-sungguh untuk bahasa Inggeris.) *

Mark only one oval.

$\begin{array}{lllll}1 & 2 & 3 & 4 & 5\end{array}$

(2) Strongly Agree (Sangat Bersetuju) $\square \bigcirc \bigcirc \bigcirc$ Strongly Disagree (Sangat Tidak Bersetuju)


6. 3. I have not gotten nervous and tense when studying my English language. (Saya tidak merasa gementar dan tertekan bila saya belajar bahasa Inggeris.) *

Mark only one oval.

$\begin{array}{lllll}1 & 2 & 3 & 4 & 5\end{array}$

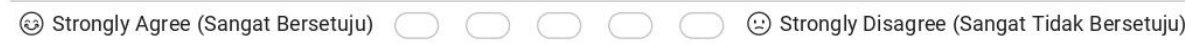

7. 4. I do not worry about my English language subject. (Saya tidak risau tentang mata pelajaran bahasa Inggeris.) *

Mark only one oval.

$\begin{array}{lllll}1 & 2 & 3 & 4 & 5\end{array}$

()ㅇ Strongly Agree (Sangat Bersetuju)

8. 5.1 do not feel capable of studying for my English language subject. (Saya rasa saya tidak berkebolehan belajar dalam mata pelajaran bahasa Inggeris.) *

Mark only one oval

$\begin{array}{lllll}1 & 2 & 3 & 4 & 5\end{array}$

(2) Strongly Agree (Sangat Bersetuju) $\square+($ Strongly Disagree (Sangat Tidak Bersetuju)

9. 6.I am more easily distracted when I study my English language subject than my other subjects. (Saya lebih mudah terganggu bila saya belajar mata pelajaran bahasa Inggeris berbanding dengan mata pelajaran yang lain.) *

Mark only one oval.

$\begin{array}{lllll}1 & 2 & 3 & 4 & 5\end{array}$

() Strongly Agree (Sangat Bersetuju)

10. 7. I feel I fall asleep more easily in my English language class than my other classes. (Saya rasa saya lebih mudah tertidur dalam kelas bahasa Inggeris berbanding dengan kelas-kelas yang lain.) *

Mark only one oval

$\begin{array}{lllll}1 & 2 & 3 & 4 & 5\end{array}$

(2) Strongly Agree (Sangat Bersetuju) 
11. 8. I feel my attention wanders more easily in my English language class than my other classes. (Saya rasa lebih mudah hilang tumpuan dalam kelas bahasa Inggeris berbanding dengan kelas-kelas yang lain.) *

Mark only one oval

$\begin{array}{lllll}1 & 2 & 3 & 4 & 5\end{array}$

(ㄱ) Strongly Agree (Sangat Bersetuju) $\square+\infty$ Strongly Disagree (Sangat Tidak Bersetuju)

12. 9. I feel nervous and afraid about participating in class discussion during my English language class. (Saya rasa gementar dan takut untuk terlibat dalam perbincangan kelas semasa kelas bahasa Inggeris.) *

Mark only one oval.

$\begin{array}{lllll}1 & 2 & 3 & 4 & 5\end{array}$

(2) Strongly Agree (Sangat Bersetuju)

13. 10. I feel that I am not in control of my grades in my English language subject. (Saya rasa tidak mampu menentukan gred saya dalam mata pelajaran bahasa Inggeris.) *

Mark only one ova.

$\begin{array}{lllll}1 & 2 & 3 & 4 & 5\end{array}$

(ㄱ) Strongly Agree (Sangat Bersetuju) $\square+\infty$ Strongly Disagree (Sangat Tidak Bersetuju)

14. 11. I feel anxious about English language exams. (Saya rasa bimbang tentang peperiksaan bahasa Inggeris.)*

Mark only one oval.

$\begin{array}{lllll}1 & 2 & 3 & 4 & 5\end{array}$

(2) Strongly Agree (Sangat Bersetuju)

15. 12. I want to learn the English language. (Saya ingin belajar bahasa Inggeris.) *

Mark only one ova

$\begin{array}{lllll}1 & 2 & 3 & 4 & 5\end{array}$

(ㅇ) Strongly Agree (Sangat Bersetuju) $\square+\infty$ Strongly Disagree (Sangat Tidak Bersetuju) 
16. 13. I define being successful in my English language subject as an A scale. (Saya menganggap berjaya dalam mata pelajaran bahasa Inggeris jika saya berada dalam skala A. *

Mark only one oval.

$\begin{array}{lllll}1 & 2 & 3 & 4 & 5\end{array}$

(2) Strongly Agree (Sangat Bersetuju) $\square \square \bigcirc \bigcirc \bigcirc$ Strongly Disagree (Sangat Tidak Bersetuju)

17. 14. I will never be successful in my English language subject. (Saya tidak akan berjaya dalam mata pelajaran bahasa Inggeris.) *

Mark only one oval.

$\begin{array}{lllll}1 & 2 & 3 & 4 & 5\end{array}$

(:) Strongly Agree (Sangat Bersetuju) $\square+\square \bigcirc$ Strongly Disagree (Sangat Tidak Bersetuju)

Section C: English Language Academic

Perceptions (Bahagian C: Persepsi

Akademik Pembelajaran Bahasa Inggeris)

\section{Instructions:}

Below are question items that assess your attitudes and perceptions concerning English language learning. Read each statement and then decide if you:

(1) Strongly Agree; (2) Agree; (3) Neutral; (4) Disagree; or (5) Strongly Disagree.

There are no right or wrong answers. We are simply interested in your opinions. Select your answers in

the appropriate boxes.

Arahan:

Di bawah ini terdapat item-item soalan untuk menilai sikap dan persepsi anda terhadap pembelajaran bahasa Inggeris. Baca setiap pernyataan dan kemudian pentukan

(1) Sangat Setulu; (2) Setuju; (3) Nentrat; (4) Tidak Setuju; atau (5)

Sangat Tidak Setuju.

Sangat Tidak Setuju.
Tidak terdapat jawapan betul atau salah. Kami hanya berminat terhadap pandangan anda. Tandakan jawapan anda dalam kotak yang berkenaan.

18. 1. I learn the vocabulary of the English language easily. (Saya mempelajari perbendaharaan kata bahasa Inggeris dengan mudahnya.) *

Mark only one oval.

$\begin{array}{lllll}1 & 2 & 3 & 4 & 5\end{array}$

(23) Strongly Agree (Sangat Bersetuju) $\square+\infty \quad$ Strongly Disagree (Sangat Tidak Bersetuju) 
19. 2. I have difficulty spelling words in an English language class. (Saya menghadapi kesukaran mengeja dalam kelas bahasa Inggeris.) *

Mark only one oval.

$\begin{array}{lllll}1 & 2 & 3 & 4 & 5\end{array}$

(ㄱ) Strongly Agree (Sangat Bersetuju)

20. 3. I learn the rules of grammar in my English language class easily. (Saya belajar tatabahasa dalam kelas bahasa Inggeris dengan mudahnya.) *

Mark only one ova:

$\begin{array}{lllll}1 & 2 & 3 & 4 & 5\end{array}$

(:) Strongly Agree (Sangat Bersetuju) $\square+\infty \square+$ Strongly Disagree (Sangat Tidak Bersetuju)

21. 4. I have difficulty in conversing/speaking in the English language. (Saya menghadapi kesukaran berbual/bercakap dalam bahasa Inggeris.) *

Mark only one oval

$\begin{array}{lllll}1 & 2 & 3 & 4 & 5\end{array}$

(ㅇ) Strongly Agree (Sangat Bersetuju) $\square+\infty$ Strongly Disagree (Sangat Tidak Bersetuju)

22. 5. I write in the English language easily. (Saya menulis dalam bahasa Inggeris dengan mudahnya.) *

Mark only one oval

$\begin{array}{lllll}1 & 2 & 3 & 4 & 5\end{array}$

(2) Strongly Agree (Sangat Bersetuju)

23. 6. I have difficulty in translating the English language into my first language. (Saya menghadapi kesukaran menterjemah bahasa Inggeris kepada bahasa pertama saya.) *

Mark only one oval.

$\begin{array}{lllll}1 & 2 & 3 & 4 & 5\end{array}$

(ㄱ) Strongly Agree (Sangat Bersetuju) $\square+\infty$ Strongly Disagree (Sangat Tidak Bersetuju) 
24. 7. I have difficulty in listening to and understanding the English language as it is spoken. (Saya menghadapi kesukaran mendengar dan memahami bahasa Inggeris apabila ianya digunakan dalam perbualan.) *

Mark only one oval

$\begin{array}{lllll}1 & 2 & 3 & 4 & 5\end{array}$

(ㄱ) Strongly Agree (Sangat Bersetuju) $\square+\infty$ Strongly Disagree (Sangat Tidak Bersetuju)

25. 8. I translate from my first language into the English language easily. (Saya menterjemah daripada bahasa pertama saya ke bahasa Inggeris dengan mudahnya.) *

Mark only one oval

$\begin{array}{lllll}1 & 2 & 3 & 4 & 5\end{array}$

(2) Strongly Agree (Sangat Bersetuju) $\square+\infty$ Strongly Disagree (Sangat Tidak Bersetuju)

26. 9. I read in my English language class easily. (Saya membaca dalam kelas bahasa Inggeris saya dengan mudahnya.)*

Mark only one oval

$\begin{array}{lllll}1 & 2 & 3 & 4 & 5\end{array}$

(ㄱ) Strongly Agree (Sangat Bersetuju) $\square \square \square \square$ Strongly Disagree (Sangat Tidak Bersetuju) 